\title{
EVALUATION OF HONEY BEE VISITS ON COCONUT GENOTYPES
}

\author{
S. SADAKATHULLA \\ Professor (Agricultural Entomology) \\ Coconut Research Station, Veppankulam - 614906 \\ S. India
}

\section{ABSTRACT}

The three species of honey bees viz., Indian bee Apis cerana indica F. little bee, Apis florea F. and dammer bee, Melipona iridipennis D. were observed in different proportions in the inflorescence of 47 coconut genotypes comprising 28 varieties and 19 hybrids. The number of Indian bees visiting was 2.5 times more than the dammer bee. The number of honey bees visiting the hybrids was 36 percent more than the varieties.

\section{INTRODUCTION}

The coconut palm (Cocos nucifera $\mathrm{L}$.) is a cross pollinated perennial crop through the agency of wind and insects. It is a good source of pollen and nectar throughout the year. The secretion of nectar by the glands situated in the male and female flowers of coconut has been recorded by Huggins (1928) and Narayana (1937). The groove present in the pollen indicated that the type adapted to be carried by the insect (Menon and Pandalail' 1958). Among insecis, honey bees, bumble bee, house fly, ants were recorded as pollinators in coconiut palm. Petch (1913) stated that the main made of pollination was through insects including ants. In Philippines, little pollen is carried by wind from one tree to another and pollination is ahiefly effected by insects, the most important among them being the house fly (Musca domestica), several species of Lasila (Diptera) and Apis indica (Aldaba, 1921). Subsequently Furtado (1924) listed other possible agents in coconut pollination. The black ant (Camponotus compressus F.) $_{\text {) }}$ was the other important pollinator in coconut palm. Henry Louis and Chelladurai (1984) recorded the various species of insect pollinators and their frequency of visits in relation to matured male and female flowers in coconut. Sadakathulla and Ramachandran (1991) found that the conventional light trap in coconut garden trapped more honey bees. The present study was undertaken to record different honey bee species aiding cross pollination in coconut and evaluate the effective species on 47 coconut genotypes at Coconut Research Station, Veppankulam, S. India during 1992.

\section{MATERIALS AND METHODS}

Forty seven coconut genotypes comprising 28 varieties and 19 hybrids were observed @ thrce palms per genotype. Among insect pollinators, different honey bee species visiting the inflorcscence of palms age ranging from 8 to $30 \mathrm{yrs}$ at Coconut Research Station, Veppankulam, S. India were recorded. The number of bees visited the inflorescence in each palm of the genotype were actually counted for $30 \mathrm{~min}$. between $7.00 \mathrm{AM}-7.30 \mathrm{AM}$ in early hours during bright days. The observations were completed in 11 days. The mean data were analysed. 


\section{RESULTS}

The common species of honey bee observed were Indian bee, Apis cerana indica F., little bee Apis dorsata F. and dammer bee, Melipona iridipennis D. in different proportions.

The number of bees that visited the coconut inflorescence ranged from 1-6,1 - 14 and 2-18 with a mean of 3,4 and 7 numbers in varieties and $1-6,1-16$ and $4-20$ with a mean of 4,6 and 9 numbers in hybrids for dammer bee ( $M$. iridipennis), little bee ( $A$. florea) and Indian bee ( $A$. $C$. Indica) respectively. The ratios of bee species visiting the inflorescence were $1: 1.5: 2.5$ and 1 : $1.7: 2.5$ for dammer bee, little bee and Indian bee respectively (Tables $1 \& 2$ ).

Table 1 Range and mean of honey bees on coconut inflorescence

\begin{tabular}{lcccc}
\hline S. No. & \multicolumn{2}{c}{ Range in } & \multicolumn{2}{c}{ Pooled mean per } \\
& Variety & Hybrid & *Variety & **Hybrid \\
\hline 1. Indian bee & $2-18$ & $4-20$ & 7 & 9 \\
2. Little bee & $1-14$ & $1-16$ & 4 & 6 \\
3. Dammer bee & $1-6$ & $1-6$ & 3 & 4 \\
\hline
\end{tabular}

* Mean of 28 coconut varietics

** Mean of 19 coconut hybrids

Table 2 Ratio of different honey bees on coconut genotypes

\begin{tabular}{lllll}
\hline $\begin{array}{c}\text { S. No. Coconut } \\
\text { genotype }\end{array}$ & Ratio of Dammer bee : & Little bee & Indian bee \\
\hline 1. & Varieties & $1: 1.5$ & $:$ \\
& & $1: 1.7$ & $:$ & 2.5 \\
\hline
\end{tabular}

The mean number of Indian bee visiting was 2.5 times more than the dammer bee. The number of honey bees visiting the inflorescence of hybrid coconut was 36 per cent more than in varieties.

Among the 28 varieties, the following viz, LM, STG, GB, NCD, Phl, Ay, COD, ECT, Gu, NG, GD and San Blas were found significantly superior in recoiding more number of honey bees (Table-3). Among the 19 hybrids, the following viz.. VHC-1, VHC-2, and WCT X COD were significantly superior, closely followed by Ph 1 x GD, ECT x STG, GD x STY and Si x GD in recording more number of honey bces in the inflorescence for the effective cross pollination (Table - 4).

\section{DISCUSSION}

Coconut palm, cssentially a cross pollinated crop, depends upon different agents for cross pollination, of which, insects play a major rolc. Among insects, three species of honey bees in varied proportions were recorded for effective cross pollination. 
Table 3 Honey bees visiting the inflorescence of coconut varieties

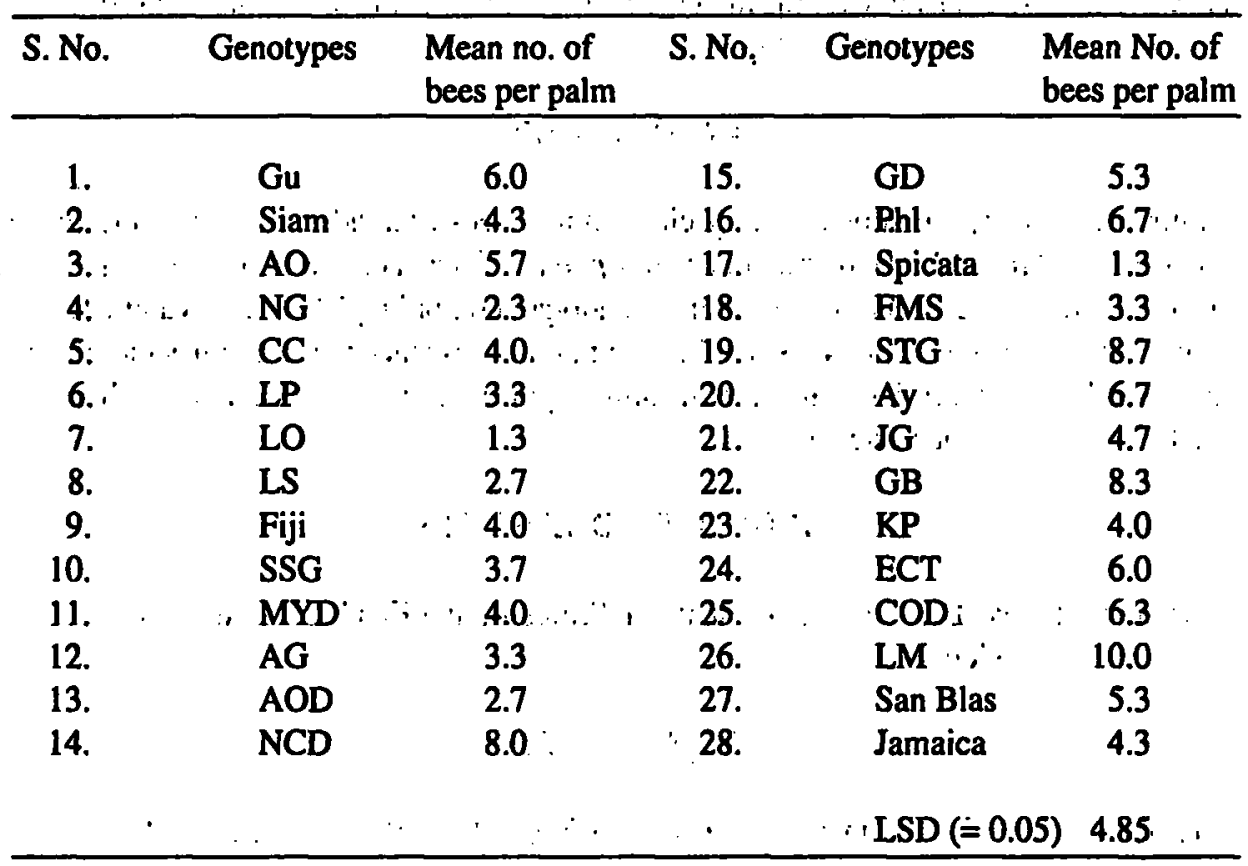

The mean number of Indian bees (A. C. Indica) visiting the coconut inflorescence.was 2.5 times more than the dammer bee ( $M$. Iridipennnis). Twelve varieties were found significantly superior and recorded more number of all the three species of honey bees. All the three species of honey bees were on par in. visiting the coconut inflorescence. However the inflorescence of the coconut genotypes viz., GB, NCD and STG were visited by more number of Indian bees, little bees and dammer bees respectively. Three hybrids viz., VHC-1, VHC-2 and WCT x COD were significantly superior followed by four hybrids and recorded more number of bees. Among the three species of honey bees, Indian bee was found significantly superior while the little bee and dammer bee were on par in visiting the inflorescence of hybrid coconut palms.

Table 4 . Honey bees visiting the inflorescence of coconut hybrids

\begin{tabular}{lllll}
\hline S. No. Genotypes & $\begin{array}{l}\text { Mean No. of } \\
\text { bees per palm }\end{array}$ & $\begin{array}{l}\text { S. No. } \\
\text {. }\end{array}$ & Genotypes & $\begin{array}{l}\text { Mean No. of } \\
\text { bees per palm }\end{array}$ \\
\hline
\end{tabular}

1. $\mathrm{ECT} X \mathrm{MGD}=(\mathrm{VHC}-1), \quad 14.0$

11. $\quad$ Phl $\times$ CC

2. $E C T X M Y C=(V H C-2)$

12.7

12... Phl $\times$ MYD

3. ECT X Ay

2.3

4. ECT X STG

6.7

5. ECT X STY

13.

$\mathrm{CC} \times \mathrm{Phl}$

6. ECT X STR

14.

LO X CC

15.

7. WCT X COD

16.

STG X ECT

8. Siam $x$ Ay

10.0

9. Ay $x$ Siam

3.0

17.

STY X ECT

18.

STR X ECT

10. Siam $\times$ MYD

6.3

19. STY X MYD

LSD $(=0.05)$ 
The number of honey bees visiting the inflorescence by hybrid coconut was 36 per cent more than in varieties also contribute for the increased button (female flower) setting, consequently the higher yield in hybrid coconut genotypes.

\section{CONCLUSION}

Among the insect pollinators, three species of honey bees viz., Indian bee, Apis cerana indica F; little bee Apis florea $F$. and dammer bee, Melipona iridipennis $D$. were recorded in different proportions in the inflorescence of 47 coconut genotypes comprising 28 varieties and 19 hybrids. The mean number of Indian bees visited the coconut inflorescence was 2.5 times more than the dammer bees both in the varieties and hybrid palms. Hybrids attracted more number of honey bees i.e., 36.0 percent over the varieties.

\section{ACKNOWLEDGEMENTS}

The author thanks Dr. T. K. Ramachandran, Professor and Head, Coconut Research Station for the facilities provided.

\section{REFERENCES}

Aldaba, V.C. (1921) The pollination of coconut. Philipp Agriculturist $10: 195$ - 210.

Furtado, C. X. (1924) A study of coconut flower and its relation to fruit production. Gard. Bull. 3 : 261 - 274.

Henry Louis, I. and M. Chelladurai. (1984) Nature and frequency of insects pollinating the coconut palm (Cocos nucifera L.) Indian Coconut J. 15 (8) : 1 - 6.

Huggins, H.D. (1928) Pollination and Crop production. Agric. J. Brit. Guiana 1 : 164.

Menon, K.P.V. and K. M. Pandalai 1958. The coconut palm - A monograph. ICAR. Ernakulam. Kerala. S. India. pp. 65 - 68.

Narayana, G.V. 1937. On the nectar secretion of coconut flowers, Cocos nucifera Linn. Proc. Indian Acad. Sci. 6, 4, 224.

Petch, T. 1913. The flowers of coconut palm. Trop Agriculturist. 41449 - 55.

Sadakathulla, S. and T. K. Ramachandran, 1991. Light traps kill honey bees. Bee Keeping \& Development (UK). Sep. 1991 (20) : 8. 